УДК: 616.379-008.64-002.3-092:612.115

\section{C.Ю. Kapamєєва}

Буковинський державний медичний університет, м. Чернівці

\author{
ВИВЧЕННЯ ВПЛИВУ ОЗОНОТЕРАПІЇ НА \\ ЗМІНИ ПОКАЗНИКІВ ФІБРИНОЛІЗУ, \\ ПРОТЕОЛІЗУ КРОВІ \\ ЕКСПЕРИМЕНТАЛЬНИХ ЩУРІВ ЗА \\ НАЯВНОСТІ ГНІЙНО-ЗАПАЛЬНИХ \\ ПРОЦЕСІВ НА ФОНІ ЦУКРОВОГО \\ ДІАБЕТУ
}

Ключові слова: цукровий діабет, гнійно-запальні ускладнення, фібриноліз, протекторні властивості, озонотерапія

Резюме. Експериментальні дослідження на 35 білих щурах із гнійно-запальними процесами на фоні иукрового діабету із застосуванням озонотерапії виявили покращення показників регулячії агрегатного стану крові, зменшення проявів гіперкоагуляиії: зростання часу рекальціфікації плазми крові, активованого париіального тромбопластинового часу, протромбінового часу, тромбінового часу, активачії тромбоцитарно-судинного гемостазу, виявлено істотні протекторні властивості зі зниженням лізису азоальбуміну, сумарної, не ферментативної фібринолітичної активності та активності протеїназ за Кунітиом у плазмі крові.

\section{Вступ}

Актуальність цукрового діабету зумовлена тим, що більше ніж у 30-70 \% хворих виникають гнійно-запальні процеси і 50 \% госпіталізованих хворих потребують хірургічної допомоги 3 приводу гнійно-некротичних ускладнень $[2,5]$. Швидке прогресування гнійно-некротичного вогнища зумовлене розвитком поліморфної аеробної і анаеробної неклостридіальної інфекції, яка часто не чутлива до більшості антибіотиків $[3,5]$. Гнійна інфекція та цукровий діабет (ЦД) взаємо-обтяжують перебіг одне одного. Летальність при ЦД з гнійною хірургічною інфекцією, як і декілька десятків років тому, залишається високою - від 6 до 44,4 \% [1, 4].

Таким чином, гнійно-запальні ускладнення м'яких тканин у хворих на ЦД є складною проблемою хірургії. Тому перебіг гнійно-запальних процесів м'яких тканин у хворих на ЦД потребує подальшого вивчення з метою оптимізації його корекції.

\section{Мета дослідження}

Вивчити вплив озонотерапії на перебіг гнійнозапальних процесів при цукровому діабеті в експерименті.

\section{Матеріал і методи}

Експериментальні дослідження проведені на 35 білих статевозрілих щурах. Контрольна група (8). Цукровий діабет моделювали шляхом підшкірного уведення алоксану (100 мг на кг маси тіла). Щури першої дослідної групи (10) отри- мували підшкірне уведення калової суспензії (пул калу від 20 тварин розводили у $0,9 \%$ розчині хлориду натрію) у дозі 0,5 мл на 100 г маси тіла. На 14-ту добу після уведення алоксану тваринам другої дослідної групи (9) підшкірно вводили 10\%-у калову суспензію. Тваринам третьої групи (8) з модельованим ЦД калову суміш уводили підшкірно і надалі впродовж трьох діб один раз на день внутрішньоочеревинно уводили з розрахунку 1,0 мл на 100 г маси тіла тварини 1 раз на добу впродовж 3 діб озонований 0,9 \% розчин натрію хлориду.

Озонацію стерильного 0,9 \% розчину хлориду натрію проводили на апараті "Бозон" до концентрації озону в ізотонічному розчині хлориду натрію 20 мкг/мл.

\section{Обговорення результатів дослідження}

Оцінка стану системи необмеженого протеолізу, активності фібринолізу та молекул середньої маси плазми крові за умов перебігу гнійних процесів шкіри і підшкірної клітковини в статевозрілих щурів виявила зростання лізису азоказеїну та концентрації молекул середньої маси плазми крові (табл. 1).

Оцінка стану системи регуляції агрегатного стану крові за умов розвитку гнійних процесів у статевозрілих щурів виявили (табл.2) зниження часу рекальцифікації плазми крові, тромбінового часу, зростали відсоток адгезивних тромбоцитів та індекс спонтанної агрегації тромбоцитів, що вказувало на активацію тромбоцитарно-судин- 
Таблиця 1

Стан системи необмеженого протеолізу, активності фібринолізу та молекул середньої маси плазми крові за умов перебігу гнійно-запальних процесів м'яких тканин у статевозрілих щурів $(\mathbf{x} \pm \mathbf{S x})$

\begin{tabular}{|c|c|c|}
\hline Показники & $\begin{array}{l}\text { Контроль } \\
(\mathrm{n}=8)\end{array}$ & $\begin{array}{c}\text { Основна } \\
\text { Уведення калової } \\
\text { суспензії }(\mathrm{n}=10)\end{array}$ \\
\hline Лізис азоальмуміну, мкг/мл соод & $2,24 \pm 0,351$ & $2,39 \pm 0,329$ \\
\hline Лізис азоказеїну, мкг/мл год & $1,87 \pm 0,227$ & $3,00 \pm 0,209$ \\
\hline Лізис азоколагену, мкг/мл год & $0,77 \pm 0,137$ & $1,14 \pm 0,176$ \\
\hline Сумарна фібринолітична активність, мкг/мл год & $4,23 \pm 0,486$ & $4,78 \pm 0,489$ \\
\hline $\begin{array}{l}\text { Неферментативна } \text { фібринолітична } \\
\text { мкг/мл год }\end{array}$ & $1,88 \pm 1,05$ & $1,11 \pm 0,175$ \\
\hline $\begin{array}{l}\text { Активність протеїназ за Кунітцом- казеїнолітичні } \\
\text { одиниці, калібровані за трипсином }\end{array}$ & $0,19 \pm 0,029$ & $0,27 \pm 0,031$ \\
\hline Концентрація молекул середньої маси, ум. од. & $0,12 \pm 0,015$ & $0,18 \pm 0,018$ \\
\hline
\end{tabular}

p - вірогідність різниць порівняно з контролем, n- число спостережень.

Таблиця 2

Стан системи регуляції агрегатного стану крові за умов перебігу гнійних процесів м'яких тканин у статевозрілих щурів $(\mathbf{x} \pm \mathbf{S x})$

\begin{tabular}{|c|c|c|}
\hline Показники & $\begin{array}{l}\text { Контроль } \\
(\mathbf{n}=8)\end{array}$ & $\begin{array}{c}\text { Основна } \\
\text { Уведення калової } \\
\text { суспензії }(\mathrm{n}=10)\end{array}$ \\
\hline Час рекальціфікації плазми, с & $101,5 \pm 2,38$ & $90,8 \pm 2,33 \quad \mathrm{p}<0$ \\
\hline Активований парціальний тромбопластиновий час, с & $42,5 \pm 2,32$ & $35,8 \pm 2,35$ \\
\hline Протромбіновий час, с & $16,4 \pm 1,38$ & $13,2 \pm 1,37$ \\
\hline Тромбіновий час, с & $14,5 \pm 0,97$ & $10,9 \pm 1,07$ \\
\hline Концентрація фібриногену в плазмі крові, г/л & $4,48 \pm 0,179$ & $4,80 \pm 0,175$ \\
\hline Активність антитромбіну III, \% & $98,2 \pm 3,53$ & $104,6 \pm 3,37$ \\
\hline Активність XIII фактора згортання крові, \% & $94,9 \pm 3,74$ & $96,5 \pm 3,35$ \\
\hline $\begin{array}{l}\text { Відсоток адгезивних тромбоцитів за методом Міщенка, } \\
\%\end{array}$ & $2,69 \pm 0,362$ & $4,90 \pm 0,358$ \\
\hline $\begin{array}{l}\text { Індекс спонтанної агрегації тромбоцитів за методом } \\
\text { Tacolla, \% }\end{array}$ & $28,3 \pm 1,91$ & $34,4 \pm 1,90$ \\
\hline Хагеман залежний фібриноліз, хв & $16,9 \pm 0,68$ & $13,4 \pm 0,66$ \\
\hline Потенційна активність плазміногену, хв & $15,8 \pm 1,26$ & $12,4 \pm 1,19$ \\
\hline Антиплазміни, \% & $93,0 \pm 4,75$ & $100,6 \pm 4,48 \mathrm{p}<0,05$ \\
\hline
\end{tabular}

плазми крові.

Скорочення часу Хагеман-залежного фібринолізу було мало ефективним у протидії зазначеним змінам активації гіперкоагуляції.

Цукровий діабет істотно ускладнював перебіг гнійних процесів. На що вказувало істотне зростання протеолізу за лізисом азоальбуміну, азоказеїну, азоколагену, підвищувалися сумарна, неферментативна фібринолітична активність та активність протеїназ за Кунітцом (табл. 3). Про наростання ступеня інтоксикації свідчило зростання молекул середньої маси. Цукровий діабет також викликав істотні порушення системи гемостазу за умов та наявності гнійних процесів. Так, виявлено істотне зростання гіпер-коагуляції плазми крові за зниженням часу рекальціфікації, активованого парціального тромбоцитарнотромбінового часу. Зниження концентрації 
ного гемостазу та згортальної системи .

Застосування озонотерапії за умов перебігу гнійно-запальних процесів при ЦДу статевозрілих щурів виявляло істотні протекторні властивості, на що вказувало зниження лізису азоальбуміну, сумарної, не ферментативної фібринолітичної активності та активності протеїназ за Кунітцом у плазмі крові (табл. 3).
Озонотерапія покращувала також показники регуляції агрегатного стану крові за умов наявності гнійних процесів при ЦД у статевозрілих щурів. Це виявлялося у зменшенні проявів гіперкоагуляції, на що вказувало зростання часу рекальцифікації плазми крові, активованого парціального тромбопластинового часу, протром-

Стан системи необмеженого протеолізу, активності фібринолізу та концентрація молекул середньої маси плазми крові за умов перебігу гнійно-запальних процесів м'яких тканин при цукровому діабеті на фоні озонотерапії у статевозрілих щурів (x \pm Sx)

\begin{tabular}{|c|c|c|}
\hline Показники & $\begin{array}{c}\text { Уведення калової } \\
\text { суспензії при ЦД }(n=9)\end{array}$ & $\begin{array}{c}\text { Уведення калової } \\
\text { суспензії при ЦД на } \\
\text { фоні озонотерапії } \\
(\mathrm{n}=8) \\
\end{array}$ \\
\hline Лізис азоальбуміну, мкг/мл ггод & $4,64 \pm 0,443$ & $3,08 \pm 0,282 \mathrm{p}<0,02$ \\
\hline Лізис азоказеїну, мкг/мл ггод & $5,95 \pm 0,744$ & $4,41 \pm 0,735 \mathrm{p}<0,01$ \\
\hline Лізис азоколагену, мкг/мл ггод & $3,57 \pm 0,743$ & $1,84 \pm 0,351 \mathrm{p}<0,01$ \\
\hline $\begin{array}{l}\text { Сумарна фібринолітична активність, мкг/мл } \\
\text { год }\end{array}$ & $9,84 \pm 0,838$ & $6,34 \pm 0,709 \mathrm{p}<0,01$ \\
\hline $\begin{array}{l}\text { Неферментативна фібринолітична активність, } \\
\text { мкг/мл ггод }\end{array}$ & $7,55 \pm 1,495$ & $1,42 \pm 0,198 \mathrm{p}<0,01$ \\
\hline \begin{tabular}{lccc} 
Активність & протеїназ & за & \multicolumn{2}{c}{ Кунітцом- } \\
казеїнолітичні & одиниці, & калібровані & за \\
трипсином & & & \\
\end{tabular} & $0,89 \pm 0,103$ & $0,31 \pm 0,142 \mathrm{p}<0,01$ \\
\hline Концентрація молекул середньої маси, ум. Од. & $0,30 \pm 0,034$ & $0,32 \pm 0,039$ \\
\hline
\end{tabular}

Таблиця 4

Стан системи регуляції агрегатного стану крові за умов перебігу гнійно-запальних процесів м'яких тканин при цукровому діабеті на фоні озонотерапії у статевозрілих щурів (x $\pm \mathbf{S x})$

\begin{tabular}{|c|c|c|}
\hline Показники & $\begin{array}{c}\text { Уведення калової } \\
\text { суспензії при ЩД } \\
(\mathrm{n}=9)\end{array}$ & $\begin{array}{c}\text { Уведення калової } \\
\text { суспензії при ЩД на } \\
\text { фоні озонотерапії }(\mathrm{n}=8)\end{array}$ \\
\hline Час рекальцифікації плазми, с & $67,7 \pm 4,39$ & $\begin{array}{l}84,8 \pm 2,01 \quad p<0,01 \\
\end{array}$ \\
\hline $\begin{array}{l}\text { Активований парціальний тромбопластиновий час, } \\
\text { с }\end{array}$ & $21,3 \pm 1,73$ & $37,1 \pm 2,39$ \\
\hline Протромбіновий час, с & $9,31 \pm 0,869$ & $14,0 \pm 1,38$ \\
\hline Тромбіновий час, с & $7,11 \pm 0,579$ & $10,9 \pm 0,77$ \\
\hline Концентрація фібриногену в плазмі крові, г/л & $2,99 \pm 0,161$ & $3,55 \pm 0,225 \mathrm{p}<0,05$ \\
\hline Активність антитромбіну III, \% & $99,1 \pm 6,90$ & $116,3 \pm 5,35 \mathrm{p}<0,05$ \\
\hline $\begin{array}{llll}\text { Концентрація розчинних } & \text { комплексів } & \text { фібрин- } \\
\text { мономеру в крові, мкг/л } & & \\
\end{array}$ & $3,25 \pm 0,403$ & $7,57 \pm 0,693$ \\
\hline Активність ХІІІ фактора згортання крові, \% & $88,8 \pm 7,61$ & $91,9 \pm 5,48$ \\
\hline $\begin{array}{l}\text { Відсоток адгезивних тромбоцитів за } \\
\text { Міщенка, \% }\end{array}$ & $11,95 \pm 0,558$ & $8,60 \pm 0,687$ \\
\hline $\begin{array}{l}\text { Індекс спонтанної агрегації тромбоцитів за методом } \\
\text { Tacolla, \% }\end{array}$ & $45,7 \pm 2,07$ & $33,8 \pm 2,46$ \\
\hline Хагеман залежний фібриноліз, хв & $9,67 \pm 0,758$ & $11,8 \pm 1,06 \quad \mathrm{p}<0,01$ \\
\hline Потенційна активність плазміногену, хв & $10,3 \pm 0,69$ & $8,33 \pm 0,810 \quad \mathrm{p}<0,01$ \\
\hline Антиплазміни, \% & $112,9 \pm 5,36$ & $115,9 \pm 5,10$ \\
\hline
\end{tabular}


бінового часу, тромбінового часу (табл. 4). На зниження патогенного впливу активації тромбоцитарно-судинного гемостазу вказувало зниження відсотка адгезивних тромбоцитів за Міщенко та індекса спонтанної агрегації тромбоцитів за методом Tacolla. Додаткові антикоагулянтні властивості за цих умов виявляло наростання концентрації розчинних комплексів фібринмономеру.

Такі зміни у статевозрілих щурів можна розцінювати позитивно щодо перебігу гнійнозапального процесу: зниження інтоксикації, зростанням протекторних властивостей, зменшенням проявів гіперкоагуляції на фоні хронічного перебігу ЦД.

\section{Висновки}

1.Застосування озонотерапії за умов наявності гнійників м'яких тканин при ЦД у статевозрілих щурів виявляс істотні протекторні властивості зі зниженням лізису азоальбуміну, сумарної, не ферментативної фібринолітичної активності та активності протеїназ за Кунітцом у плазмі крові.

2. Озонотерапія покращує показники регуляції агрегатного стану крові за умов перебігу гнійнозапальних процесів при ЦД в статевозрілих щурів із зменшенням проявів гіперкоагуляції: зростання часу рекальцифікації плазми крові, активованого парціального тромбопластинового часу, протромбінового часу, тромбінового часу.

Література. 1. Беляков Н.А. Сахарный диабет как основной компонент патогенеза метаболического синдрома / Н.А.Беляков, С.Ю.Чубриева // Мед. Акад. Ж.- 2009.- Т. 8, № 1.- С. 116-127. 2. Малахов В.А. Реологические свойства крови у больных с диабетической полийнеропатией при комплексном лечении с использованием озонотерапии / В.А.Малахов, Т. Т. Джанелидзе //Укр. вісник психоневрології.-2009.-Т.17, № 3 (60).-С.15-17. 3. Мумладзе Р.Б. Озонотерапия в коррекции свободнорадикальной и ферментной активности у больных перитонитом / Р.Б. Мумладзе, И.Т. Васильев, В.Н. Яковлев, О.Е. Колесова, А.В. Власенко, С.С. Лебедев // Кл. анестезиология и реаниматология. -2009. -Т.6, № 1. - С.14-21. 4.Полийчук Т.П. Изучение клинической эффективности кислородноозоновой терапии при коррекции локальных жировых отложений / Т.П.Полийчук, Т.Н.Королькова // Рос. ж. кожных и венерических болезней. - 2009. - № 5. - С. 58-62. 5. Шестакова М.В. Анемия, микроангиопатия и макроангипатия при сахарном диабете / М.В.Шестакова, Л.В.Козловская, С.А.Мартынов, С.В.Моисеев // Кл. фармакология и терапия. - 2009. - № 18(2). -С. 83-86.

\section{ИЗУЧЕНИЕ ВЛИЯНИЯ ОЗОНОТЕРАПИИ НА ИЗМЕНЕНИЯ ПОКАЗАТЕЛЕЙ ФИБРИНОЛИЗА, ПРОТЕОЛИЗА КРОВИ ЭКСПЕРИМЕНТАЛЬНЫХ КРЫС ПРИ НАЛИЧИИ ГНОЙНО- ВОСПАЛИТЕЛЬНЫХ ПРОЦЕССОВ НА ФОНЕ САХАРНОГО ДИАБЕТА.}

\section{Каратєева С.Ю}

Резюме. Экспериментальные исследования на 35 белых крысах с гнойно-воспалительными процессами на фоне сахарного диабета с применением озонотерапии обнаружили улучшение показателей регуляции агрегатного состояния крови, уменьшение проявлений гиперкоагуляции : рост времени рекальцификации плазмы крови, активированного парциального тромбопластинового времени, активации тромбоцитарно-сосудистого гемостаза, выявлены существенные протекторные свойства со снижением лизиса азоальбумину, суммарной, не ферментативной фибринолитической активности и активности протеиназ по Кунитцу в плазме крови.

Ключевые слова: сахарный диабет, гнойно-воспалительные осложнения, фибринолиз, протекторные свойства, озонотерапия.

\section{STUDY OF OZONE THERAPY INFLUENCE ON CHANGES OF INDECESIN FIBRINOLYSIS, PROTEOLYSIS OF THE BLOOD OF EXPERIMENTAL RATS IN THE PRESENCE OF PIOFLAMMATORY PROCESSES AGAINST A BACKGROUND OF DIABETES MELLITUS}

\section{S. Yu. Karateyeva}

Abstract. Experimental studies on 35 white rats with pioflammatory processes against a background of diabetes mellitus using ozone therapy revealed an improvement of the indeses of physical state regulation of the blood, decrease of hypercoagulability widense: grovth of calcitfication time of the blood plasma activationd partial ocytic-vascular thromboplastin time, thrombin time, significant protective properties with decreased lysis azoalbuminu, total, no enzymatic activity and fibrinolytic activity and proteivase activity of the blood plasma according to Kunits vere borend aut.

Key words: diabetes mellitus, pyoinflammatory processes, fibrinolysis, protective properties, ozonotherapy.

Bukovyna State Medical University (Chernivtsi).

Clin. and experim. pathol.- 2014.- Vol.13, №1 (47).-P.46-49.

Надійшла до редакиії 10.02.2014 Речензент - професор Польовий В.П.

(C) Каратєєва С.Ю., 2014 